\title{
PENGENALAN TEKNOLOGI ENSILASE HIJAUAN DI DESA TLEKUNG, KECAMATAN JUNREJO, KOTA BATU
}

\author{
Badat Muwakhid ${ }^{1 *}$, Saimul Laili ${ }^{2}$ \\ ${ }^{1}$ Fakultas Peternakan, Universitas Islam Malang \\ ${ }^{2}$ Fakultas Matematika dan Ilmu Pengetahuan Alam, Universitas Islam Malang \\ *Korespondensi email: badat. muwakhid@unisma.ac.id
}

\begin{abstract}
ABSTRAK
Permasalahan rutin yang kerap dialami peternak di Desa Tlekung, Kec. Junrejo, Kota Batu adalah sulitnya memenuhi kebutuhan pakan hijauan disaat musim kemarau. Di satu sisi, Desa Tlekung berdampingan dengan lereng Gunung Panderman, yang didalamnya terdapat hutan dengan potensi hijauan sebesar 141.636 ton per tahunnya. Lahan hutan sanggup memasok kebutuhan pakan hijauan disaat musim penghujan, namun hijauan menjadi kering dan langka pada musim kemarau. Akibatnya, peternak mengupayakan pemenuhan kebutuhan pakan pada musim kemarau melalui penggunaan jerami padi. Walaupun demikian, cadangan jerami hasi penanaman di lahan sawah di Desa Tlekung tidak mencukupi untuk memenuhi kebutuhan pakan. Usaha dalam mengatasi kekurangan pakan di musim kemarau dilakukan dengan membeli jerami padi dari luar kecamatan. Upaya ini bukanlah solusi yang tepat guna dalam mengatasi kekurangan hijauan, karena nilai nutrisi yang terkandung dalam jerami padi tidak dapat mencukupi kebutuhan hidup sapi dan domba. Tujuan yang ingin dicapai dalam program pengabdian ini adalah untuk mengenalkan, meningkatkan kesadaran dan memotivasi peternak agar mampu serta berkeinginan untuk menerapkan teknologi ensilase, guna menghasilkan silase sebagai cadangan pakan hijauan disaat musim kemarau. Berdasarkan hasil tahapan evaluasi yang telah dilakukan, tingkat keberhasilan dapat melebihi target kriteria keberhasilan yang telah dilakukan. Secara umum, peserta menyatakan penyelenggaraan pelatihan adalah hal yang penting dan dibutuhkan, dimana peserta menyatakan memahami materi yang diberikan, mampu mempraktekkan pembuatan silase, serta sebagian peserta akan mengimplementasi pembuatan silase. Dengan demikian, kegiatan pendampingan ini dapat dikatakan berhasil, karena mampu meningkatkan pengetahuan dan kemampuan peserta dalam mengikuti kegiatan pengabdian.
\end{abstract}

Kata Kunci: kelangkaan hijauan; kemarau, silase.

\section{PENDAHULUAN}

Desa Tlekung merupakan desa yang terletak di Kecamatan Junrejo, Kota Batu. Desa ini memiliki kondisi suhu rata-rata 25-28oC dengan curah hujan rata-rata pertahun selama 6 bulan. Desa Tlekung berada dalam kawasan pinggiran hutan milik Badan Usaha Milik Pemerintah (BUMN) yaitu Perum Perhutani yang membujur dari arah Timur ke Barat sepanjang kurang lebih $3 \mathrm{KM}$, berdampingan dengan lereng Gunung Panderman dengan ketinggian wilayah 600 mdpl. Luasan lahan hutan milik Pertum Perhutani seluas $1628 \mathrm{Hg}$ dengan potensi lahan subur seluas $50 \mathrm{Ha}$, dan $121 \mathrm{Ha}$ merupakan lahan dengan tingkat kesuburan rendah.

Masyarakat Desa Tlekung pada umumnya memiliki usaha sampingan yaitu beternak. Sebanyak 985 orang beternak sapi, dan 410 orang beternak domba. Populasi ternak di Desa 
Tlekung terdapat sebanyak 1479 sapi, dan 1320 domba. Dalam memenuhi kebutuhan hijauan, masyarakat Desa Tlekung memanfaatkan sumber pakan hijauan yang melimpah dari hutan. Namun, permasalahan yang tiap tahun kerap terjadi secara rutin adalah sulitnya memenuhi kebutuhan hijauan pada saat musim kemarau. Lahan hutan tidak dapat memasok kebutuhan pakan hijauan disaat musim kemarau karena hijauan menjadi kering dan langka. Akibatnya, upaya peternak dalam pemenuhan kebtuhan hijauan dilakukan melalui pemberian pakan hijauan yang berasal dari jerami padi. Produksi jerami pad hasil penanaman di Desa Tlekung sendiri tidak dapat mencukupi kebutuhan, sehingga harus membeli dari luar kecamatan Junrejo.

Pemberian pakan jerami di musim kemarau untuk mengganti rumput bukanlah solusi yang tepat guna, karena nilai nutrisi yang terkandung dalam jerami pada tidak mencukupi kebutuhan hidup sapi dan domba (Muwakhid, 2007). Kebutuhan protein untuk hidup pokok sapi dan domba adalah 7\%, selebihnya protein akan dibentuk menjadi daging. Jerami padi memiliki kandungan protein kasar hanya sebesar 3\%, sehingga diperlukan pakan selingan berprotein tinggi (tanaman leguminosa) agar dapat mencukupi hidup pokok, serta meningkatkan bobot badan.

Teknologi ensilase merupakan metode pembuatan bahan awetan hijauan yang disebut silase. Silase adalah produk olahan fermentasi bahan pakan yang dapat disimpan dalam kondisi tanpa udara (anaerob) dalam waktu yang cukup lama (Rees, 1997). Pakan hijauan ialah bahan pakan ternak yang berasal dari batang, tangkai, maupun daun tanaman, tidak termasuk buah, biji dan umbi. Hijauan yang dibuat silase disimpan dalam kondisi anaerob dan mengalami proses fermentasi anaerob oleh bakteri asam laktat yang menempel pada hijauan sejak tanaman masih hidup (Moisio dan Heikonen, 1993) Bakteri asam laktat yang menempel pada tanamanan mula-mula berstatus dorman dalam kondisi aerob, namun akan aktif pada kondisi lingkungan anaerob (Baytok dan Aksu, 2005). Bakteri asam laktat selain menghasilkan asam-asam laktat, juga menghasilkan hidrogen peroksida yang terbentuk dari nicotinamide adenin dinucleotide (NADH). Hidrogen peroksida dapat menghambat pertumbuhan bakteri patogen melalui proses oksidasi yang kuat terhadap sel bakteri, serta melalui pemisahan struktur dasar asam molekul asam nukleat atau protein sel (Brashears et al, 1998). Hijauan yang digunakan sebagai bahan silase harus memiliki kadar air $70-75 \%$, dan mengandung gula terlarut, sehingga populasi bakteri yang mengkonversi gula terlarut menjadi asam organik dapat bertahan (Kuicky, 2005). Selain itu, bahan aditif turut diperlukan sebagai akselerator fermetnasi dalam proses ensilase. Aditif dapat berupa substrat fermentasi seperti molases, bekatul, gamblong, buah singkong, dll (Kung, 2005). Bahan-bahan ini bermanfaat sebagai substrat pertama dalam proses perombakan karbohidrat menjadi asam laktat oleh bakteri selama proses ensilase berlangsung (Ostling dan Lingre, 1993).

Berdasarkan kondisi diatas, dengan memanfaatkan ketersediaan rumput di hutan yang melimpah selama musim hujan, serta informasi teknologi ensilase, kelangkaan hijauan selama musim kemarau dapat diatasi. Hal ini dapat menyelesaikan kesulitan pakan dan turut mampu memacu pertumbuhan ternak dan peningkatan populasi ternak di Desa Tlekung.

\section{METODE}

Program pengabdian masyarakat ini dilaksanakan dalam bentuk pendampingan melalui pelatihan dari segi teori, serta praktek penerapan tekonologi ensilase sebagai upaya penyediaan pakan ternak selama musim kemarau. Pendampingan dilaksanakan di selama 6 bulan, dimulai pada bulan Mei, dan berakhir pada bulan Oktober 2009, dan dilaksanakan di Desa Tlekung, Kecamatan Junrejo, Kota Batu. Peserta pendampingan adalah anggota kelompok petani dengan total peserta sebanyak 50 orang, yang dipilih dengan kriteria: 
Memiliki ternak, berkehendak menjadi pelopor program, dan memiliki antusiasme dalam mengadopsi teknologi baru.

Program pengabdian masyarakat ini dilakukan dengan menerapkan lima macam metode, yaitu: 1. Metode eksplorasi melalui cara Rapid Rural Appraisal (RRA), yang berfungsi untuk memahami situasi kondisi masyarakat desa seracara menyeluruh dalam waktu yang cepat; 2. Metode problem solving, yakni pemilihan tenaga-tenaga pelopor yang miliki kemampuan kerta kemauan dalam meneruskan serta menyebarluaskan teknologi baru yang disampaikan oleh pemateri; 3. Metode diskusi terbuka, yang dilakukan dengan cara memotivasi peserta tentang pentingnya penerapan teknologi ensilase, menyampaikan teori pembuatan silase yang berkualitas, serta menyampaikan manfaat pendayagunaan pakan berupa silase untuk memenuhi kebutuhan pakan harian; turut dilakukan pula peningkatan motivasi kepada peserta mengenai urgensi peningkatan jumlah populasi pemeliharaan ternak, setelah mampu mengaplikasikan teknologi ensilase; 4. Metode praktek secara partisipatif antara pemateri dan peserta; 5. Pendampingan berkala melalui kunjungan ke lokasi untuk dilakukan pengarahan, penjelasan dan evaluasi proses di kediaman peserta.

Berdasarkan uraian diatas, maka kegiatan program yang dilakukan dapat diruntut sebagai berikut: 1. Tahap prakondisi, yaitu dilakukan diskusi dengan pemimpin Bappeda Kota Batu guna mengetahui daerah prioritas yang membutuhkan pendampingan sesuai dengan tema pengabdian; 2. Ekplorasi, yakni implementasi metode RRA melalui riset tentang karakteristik desa, diperkuat dengan data sekunder potensi wilayah yang didapatkan dari kantor desa; 3. Sosialisasi program, melalui pertemuan dengan tokoh-tokoh masyarakat dan pengurus kelompok tani Desa Tlekung perihal teknologi ensilase guna pemenuhan pakan hijauan selama musim kemarau; 4. Penyeleksian tenaga pelopor sebagai peserta; 5 . Pelatihan pembuatan dan pendayagunaan sebagai pakan ternak. 6. Praktek pembuatan silase melalui praktei pengambilan tanaman jagung yang dirajang (chopping) kurang lebih $3 \mathrm{~cm}$, lalu dilakukan penjemuran selama tiga jam untuk menurunkan kadar air, selanjutnya ditambahkan aditif dilanjutkan proses pengepresan pada silo. Silo yang telah siap disimpan selama satu bulan; 7. Pembukaan silo yang telah didiamkan selama satu bulan selanjutnya diipelajari ciri-ciri perubahan yang terjadi, yang meliputi bentuk, warna, dan aroma. Disamping itu, peserta turut mempelajari silase yang gagal; 8. Pendampingan adopsi teknologi pembuatan silase. Pendampingan dilakukan bertahap, dimana pada survei pertama dilakukan konsultasi kepada seluruh peserta mengenai pemilihan tempat pembuatan silo serta diskusi agar didapatkan silo dengan kualitas baik.

\section{HASIL DAN PEMBAHASAN}

Hasil implementasi pengenalan teknologi ensilase dilakukan melalui evaluasi secara bertahap, yang mencakup tiga tahap. Tahap pertama meliputi empat kegiatan, yaitu: 1 . Pembemberian movitasi tentang pentingnya penerapan teknologi ensilase; 2 . Penyampaian teori pembuatan silase; 3. Penyampaian teori pendayagunaan pakan silase; serta 4. Pemberian motivasi pentingnya meningkatkan jumlah populasi kepemilikan ternak setelah mampu menerapkan pembuatan silase.

Tahapan kedua dilakukan evaluasi mengenai pelaksanaan praktek pembuatan silase, dan praktek mendayagunakan pakan silase untuk memenuhi kebutuhan pakan sehari-hari. Dalam tahapan evaluasi ketiga, dilakukan pada saat pelaksanaan pendampingan pembuatan silase oleh petani di kediaman masing-masing. Adapun kriteria, indikator pencapaian tujuan, serta tolak ukur yang digunakan dalam mengevaluasi kegiatan pengabdian dapat dilihat dalam Tabel 1 berikut: 
Tabel 1. Kriteria, indikator, dan tolak ukur pengabdian teknologi ensilase

\begin{tabular}{|c|c|c|c|c|}
\hline Evaluasi & $\begin{array}{c}\text { Indikator pencapaian } \\
\text { tujuan }\end{array}$ & Tolok ukur & $\begin{array}{c}\text { Kreteria } \\
\text { keberhasilan }\end{array}$ & $\begin{array}{c}\text { Tingkat } \\
\text { keberhasilan }\end{array}$ \\
\hline I.a & $\begin{array}{l}\text { Pernyataan peserta tentang } \\
\text { pentingnya } \\
\text { penyelenggaraan latihan }\end{array}$ & $\begin{array}{l}\text { Jumlah peserta yang } \\
\text { menyatakan sangat penting, } \\
\text { pentingdan tidak penting }\end{array}$ & $\begin{array}{l}\text { Lebih dari } 50 \% \\
\text { menyatakan penting }\end{array}$ & $\begin{array}{l}65 \% \text { menyatakan } \\
\text { penting }\end{array}$ \\
\hline I.b & $\begin{array}{l}\text { Pernyataan peserta tentang } \\
\text { kebutuhan terhadap } \\
\text { teknologi ensilase }\end{array}$ & $\begin{array}{l}\text { Jumlah peserta yang } \\
\text { menyatakan sangat butuh, } \\
\text { butuh dan tidak butuh }\end{array}$ & $\begin{array}{l}\text { Lebih dari } 50 \% \\
\text { menyatakan butuh }\end{array}$ & $\begin{array}{l}75 \% \text { menyatakan } \\
\text { butuh }\end{array}$ \\
\hline I.c & $\begin{array}{l}\text { Pernyataan peserta tentang } \\
\text { pemahaman terhadap } \\
\text { materi teknik pembuatan } \\
\text { silase }\end{array}$ & $\begin{array}{l}\text { Jumlah peserta yang } \\
\text { menyatakan sangat } \\
\text { memahami, memahami dan } \\
\text { tidak memahami }\end{array}$ & $\begin{array}{l}\text { Lebih dari } 50 \% \\
\text { menyatakan } \\
\text { memahami }\end{array}$ & $\begin{array}{l}55 \% \text { menyatakan } \\
\text { memahami }\end{array}$ \\
\hline I.d & $\begin{array}{l}\text { Pernyataan peserta tentang } \\
\text { pemahaman terhadap teori } \\
\text { pemberdayaan silase }\end{array}$ & $\begin{array}{l}\text { Jumlah peserta yang } \\
\text { menyatakan sangat } \\
\text { memahami, memahami dan } \\
\text { tidak memahami }\end{array}$ & $\begin{array}{l}\text { Lebih dari } 50 \% \\
\text { menyatakan } \\
\text { memahami }\end{array}$ & $\begin{array}{l}70 \% \text { menyatakan } \\
\text { memahami }\end{array}$ \\
\hline II.a & $\begin{array}{l}\text { Kemampuan peserta } \\
\text { mempraktekkan pembuatan } \\
\text { silase }\end{array}$ & $\begin{array}{l}\text { Jumlah peserta yang mampu } \\
\text { mempraktekkan pembuatan } \\
\text { silase }\end{array}$ & $\begin{array}{l}\text { Lebih dari 50\% } \\
\text { mampu }\end{array}$ & $90 \%$ mampu \\
\hline II.b & $\begin{array}{l}\text { Pernyataan peserta akan } \\
\text { menindaklanjuti latihan } \\
\text { dengan membuat silase }\end{array}$ & $\begin{array}{l}\text { Jumlah peserta yang akan } \\
\text { menindaklanjuti latihan } \\
\text { dengan membuat silase }\end{array}$ & $\begin{array}{l}\text { Lebih dari 50\% } \\
\text { mampu }\end{array}$ & $90 \%$ mampu \\
\hline III & $\begin{array}{l}\text { Perubahan kondisi } \\
\text { masyarakat memanfaatkan } \\
\text { teknologi ensilase pada } \\
\text { pemenuhan pakan ternak } \\
\text { nya }\end{array}$ & $\begin{array}{l}\text { Jumlah petani yang } \\
\text { melakukan pembuatan silase }\end{array}$ & $\begin{array}{l}\text { Jumlah petani yang } \\
\text { melakukan } \\
\text { pembuatan silase } \\
\text { lebih dari sepuluh } \\
\text { orang }\end{array}$ & $\begin{array}{l}\text { Sepuluh orang } \\
\text { petani atau tiga } \\
\text { kelompok akan } \\
\text { melakukan } \\
\text { pembuatan silase }\end{array}$ \\
\hline
\end{tabular}

Pemanfaatan teknologi ensilase dalam mengawetkan bahan hijauan dalam menghadapi kelangkaan selama musim kemarau merupakan salah satu penerapan dari proses adopsi inovasi teknologi oleh peternak. Proses adopsi inovasi teknologi oleh peternak dipengaruhi oleh kemudahan teknologi, mudah dimengerti, dipraktekkan oleh peternak, dan memberikan harapan untuk mendapatkan solusi atas masalah yang dihadapi (Wirdahayati, 2010). Dorongan motivasi dari penyuluh serta proses komunikasi efektif turut serta mempengaruhi peternak dalam mengadopsi teknologi baru

\section{KESIMPULAN}

Kegiatan penerapan teknologi ensilase hijauan di Desa Tlekung Kec. Junrejo, Kota Batu dapat dilaksanakan sesuai dengan tujuan kegiatan, serta dapat dinyatakan berhasil. Hal ini ditunjukkan dengan pernyataan peserta tentang pemahaman teori pemberdayaan silase, serta kemampuan peserta mempraktekkan pembuatan silase.

Rekomendasi berdasarkan hasil umpan balik dari peserta mengenai pemahaman materi dan kegiatan yang telah dilaksanakan, perlu dilakukan kegiatan pengabdian serupa sebagai upaya pembinaan dalam keberlanjutan pemanfaatan teknologi ensilase di tingkat petani, serta perlu adanya dana bantuan guna pembuatan silo.

\section{UCAPAN TERIMA KASIH}

Terima kasih kami ucapkan kepada Kepala Desa Tlekung, Kec. Junrejo, Kota Batu yang telah memberikan izin, bantuan fasilitas dan mendukung penuh pelaksanaan kegiatan pengabdian kepada masyarakat di Desa Tlekung, sehingga kegiatan berjalan dengan baik dan lancar. Ucapan terima kasih turut kami ucapkan kepada Lembaga Penelitian Universitas Islam Malang beserta staf yang telah membantu dalam proses administrasi, serta ketua jurusan nutrisi dan makanan ternak fakultas peternakan Universitas Islam Malang yang telah mendukung demi terlaksananya kegiatan pengabdian ini. 


\section{DAFTAR RUJUKAN}

Ballongue, J. (1993). Bifido Bacteria and Probiotic Action. In Lactic Acid Bacteria Micribiology and Functional Aspects. Salminen, S and A.V. Wright (Eds). Marcel Dekker Inc. New York. pp 245 - 249

Baytok, E., and T. Aksu. (2005). The Effects of Formic Acid, Molases and Inoculant as Silage Addititive on Corn Silage Composition Characteristics in Sheep. J. Vet. Anim. Sci. 29 : $469-474$

Brashers, M.M., S.S. Reilly and S.E. Gilliland. (1998). Antagonistic of Cells of Lactobacillus Lactis Toword Escherichia coli 0157 : H7 on Revigerated raw chicken Meat. J. of Food Protection $61: 166-170$

Dinas KLH Kota Batu, (2008). Suvai Produktivitas barbagai tanaman penutup tanah di kawasan hutan gunung panderman. Dinas kehutanan dan Lingkungan Hidup Kota Batu. Batu

Knicky, M. (2005). Possibilities to Improve Silaage Conservation. Effects of Crop, Ensiling Technology and additives. Doctoral Thesis. Swedish University of Agricultural Sciences. Uppsala.

Kung, L. (2005). A Review on Silage Additives, and Enzymes. http://www.ag.udel.edu/anfs/faculty/Kung.Articles/a-review-on-silage-additivesand.htm. Diakses 28 April 2005

McAllister, T. A., and A.N. Hristov. (2000). The Fundamentals of Making Good Quality Silage. http://www.wcds.afns.ualberta.ca.Proceedings/2000/Chapter32 Diakses 10 April 2005

McDonald, P. (1991). The Biochemistry of Silage. John Wiley end Sons. New York - Brisbane - Toronto

Meeske, R., G. Ashbell, Z.G. Weinberg, and T. Kipnis. (1993). Ensiling Forage Soghum at Two Stages of Maturity with the Addition of Lactic Acid Bacterial Inoculants. J. Anim. Feed Sci. and Technol. $43: 165-175$

Moisio. (1993). Additives to Improve the Silage Making Process of Tropical Forages. http://www.fao.org/documents/show-cdr.asp?url-file

=/DOCREP $/ 005 /$ x8486e10.htm. 11 April 2005

Murtopo, KH. (2007). Usaha Sapi Potong Komersial. Dewandaru Pres. Malang

Muhlbach, P.R.F. (2005). Additives to Improve the Silage Making Process of Tropical Forages.http://www.fao.org/documents/show-cdr.asp?url-file=/DOCREP /005/x8486e10.htm. Diakses 11 April 2005

Muwakhid, B. (2007). Teknologi Proses ensilase sampah OrganikSebagai Pakan Lengkap Domba. Laporan Penelitian. Universitas Islam Malang. Malang

Ostling, C.E., and S.E Lingnren. (1993). Lactic Acid Bacteria as Animal Probiotics. In Lactic Acid Bacteria. Salminen. S. and A. Vonwright (Eds.). Marcel Dekker. Inc. New York pp $154-165$

Rees, T.J. (1997). Review of the Literature. http://www.brigton.73.freeserve.Co.uk/tomsplace/scientific/phd/introduction/ph d-intr.htm. Diakses 5 Mei 2005

Skerman, P.J., and F. Riveros. (1990). Tropical Grasses. Food and Agriculture Organization of the United Nations. Rome

Wirdahayati, R.B. (2010) Kajian Kelayakan dan Adopsi Inovasi Teknologi Sapi Potong Mendukung Program PSDS : Kasus Jawa Timur dan Jawa Barat. Seminar Nasional Teknologi Peternakan dan Veteriner. Hal 339-346 